\title{
Perceptions Of Covid-19 Survivors: Prevention and Transmission Education Virus in Era New Normal
}

\author{
Qori Hajidah Arianti'1), Ifa Elok Magfiroh Oktaviani²), Ria Safitri ${ }^{3)}$, and Mochammad \\ Ilyas Junjunan ${ }^{4, a)}$
}

\author{
${ }^{1}$ Study Program of Islamic Broadcasting Communication, State Islamic University of Sunan Ampel \\ Surabaya \\ ${ }^{2}$ Islamic Family Law Study Program Sunan Ampel State Islamic University Surabaya \\ ${ }^{3}$ Biology Study Program at Sunan Ampel State Islamic University Surabaya \\ ${ }^{4}$ Accounting Study Program at Sunan Ampel State Islamic University Surabaya \\ a)Corresponding author: mij@uinsby.ac.id , HP: 085746424979
}

\begin{abstract}
Severe Acute Respiratory Syndrome Coronavirus 2 (SARS-CoV-2) is a new type of coronavirus that causes disorders of the respiratory system, acute pneumonia, and can lead to death. This community service is intended to provide understanding and knowledge about the prevention and transmission of COVID-19 to the wider community. This health education webinar community service activity is carried out online via Zoom. The material presented was about preventing and transmitting the virus during a pandemic according to the perception of COVID-19 survivors. Prior to the implementation of the educational webinar, participants were asked to register as well as fill out a questionnaire to measure the level of knowledge about preventing the transmission of COVID-19 (pre-test). Then at the end of the meeting, participants were asked to fill out the attendance list, and then fill out the questionnaire again (post-test). The results of the educational activity questionnaire showed that there was a good change in the level of knowledge between before and after being given educational materials with an average pre-test score of 63.84 and a post-test of 91.53 from 13 participants. So it can be concluded that this education can confirm audiovisually which can change the level of knowledge for the better.
\end{abstract}

Keywords: Covid-19, public health education, survivor

\section{INTRODUCTION}

The beginning of 2020 was shocked by the emergence of a new virus, namely Severe Acute Respiratory Syndrome Coronavirus 2 (SARS-CoV-2) or commonly called Corona Virus Disease ( COVID-19) (Otálora, 2020). Severe Acute Respiratory Syndrome Coronavirus 2 (SARS-CoV-2) is a new type of coronavirus that causes disorders of the respiratory system, acute pneumonia, and can lead to death. The SARS-CoV-2 virus can attack anyone, whether it is transmitted from humans to humans or from animals to humans (Brahmana, 2020). Over time, this corona virus undergoes gene mutations. Gene mutation is a spontaneous and hereditary gene change from the parent virus particle to its daughter virus particles. Corona viruses containing the mutated gene are called "SARS-CoV-2 wildtype", while the corona viruses containing the mutated gene are called "SARS- CoV-2 mutant". The more gene mutations in the corona virus, the more variants of SARS-CoV-2 (Parwanto, 2021).

Recently, the public has also been shocked by the emergence of the Variant Delta virus. Quoted from Tribunnews com (2021), the Delta variant was first identified to appear in India, the delta variant also known as B.1,617.2, being a new strain of the COVID-19 corona virus. It is easily contagious and more dangerous. The distribution of mutation cases of the SARS-CoV-2 virus variant Delta B1617.2 has been identified in 28 provinces of Indonesia with a total of 1,051 cases per data on August 9, 2021, which was uploaded by the Ministry of Health (Kemenkes) on August 16, 2021.

The phenomenon of the surge in COVID-19 cases has made the government take steps to issue a PPKM policy (Implementation of Community Activity Restrictions) in a 
number of areas, such as the Emergency PPKM which was implemented throughout Java and Bali from July 3, 2021 to July 20, 2021 and until this August, PPKM is still being extended. Quoted from Kompas com (2021). Jokowi said that this policy was taken because the COVID-19 pandemic in the last few days developed very quickly due to a new variant which is also a serious problem in many countries. This PPKM of course reaps pros and cons because people have to keep looking for money for their survival during this pandemic because there are still many people who are required to work outside the home. However, there are also people who respond to PPKM as a form of government policy in dealing with COVID-19 cases, which are on the rise, because it is feared that if PPKM is not treated like this, the case will be even higher. In addition, thegovernment has also tightened health programs such as using double masks when leaving the house.

The COVID-19 pandemic which has an impact on the lives of the world's people has made Indonesia a country that is quite responsive in preventing the spread or anticipating many more victims being exposed (Adi Saputra et al., 2021). Another government effort in preventing the transmission of Covid 19 is that the Indonesian government will also immunize Indonesian citizens twice. According to BA Fundrika (2021). The Indonesian government says it has created a vaccination program for COVID-19 in Indonesia. Health Minister Budi Gunadi Sadikin said the vaccination program in Indonesia would be implemented in two stages. This has been in consultation with Indonesia Immunization Technology Advisory Group (ITAGI), which is responsible for providing advice to the Minister of Health.

The first phase will start in January and April 2021. In the first phase, the vaccinated population is health workers, with a total population of 1.3 million, 17 , million agents, agents who have difficulty maintaining effective distance and over 60 years of age. Up to 21.5 million. The second stage, from April 2021 to March 2022, vaccinated 63.9 million people and 63.9 million people were at high risk of infection, of which were inhabited both economically and socially and divided by class (Rahayu, 2021). This community service is intended to provide understanding and knowledge about the prevention and transmission of COVID-19 to the wider community. How communities should spread and protect themselves in the face of a pandemic to prevent the spread and work together to strengthen awareness and understanding among them (Dewantari et al., 2021).

\section{METHOD}

This community service activity is through socialization activities that are carried out online or based on social media on line. This online education provision uses the applicationzoom about education on prevention and transmission of the virus during the pandemic according to the perception of COVID-19 survivors. The target audience for this activity is the general public. This activity was carried out for 1 (one) meeting, namely on August 15, 2021. With the material provided for 2 hours of learning, and as many as 13 people (15\% Male and $85 \%$ Female) had participated in this activity.

Prior to the implementation, we distributed pamphlets to several groups by attaching a registration link and offering benefits in the form of 2 OVO balances and 2 balances. ShopeePay for participants who take part in the activity from beginning to end and also participants who value Pre-test and Post-test its the highest. In the registration link, participants are also asked to fill out a questionnaire to measure the level of knowledge about preventing the transmission of COVID-19 (pre-test). After registering and filling pretest, participants will be directed to WhatsApp groups to receive information related to activities and zoom links during the socialization.

The implementation of this socialization activity starts at 19:30 WIB until 21:30 WIB. The activity was carried out at night due to the consideration of the free time of the participants who were the general public and most of them worked from morning to evening. Then at the end of the meeting, participants were asked to fill out the attendance 
list, and re-fill the questionnaire (post-test). Implementation of registration, pre-test and post-test done using the form online.

The material presented, in general, contains two things, namely: 1) Knowledge about COVID-19 and prevention of transmission; and 2) Sharing the experience of one of the survivors of COVID-19, as well as his struggle to recover from the corona virus. The measurement of the success of this program uses a comparison of the average resultspre-test with result post-test.

\section{RESULTS}

The results of outreach activities to the public about education on the prevention and transmission of COVID-19 through the perception of the survivors. Participants who took part were based on the characteristics of the respondents, gender, age of residents, and status of residents, totaling 13 people according to Table 1 (Attached Document). Based on Table 1, the characteristics of the respondents, the majority of residents who attended health education on the prevention and transmission of COVID-19 were women, 11 of the 13 webinar participants. From these data, $69 \%$ of respondents were dominated by the age of 21-30 years as many as 9 people from 13 webinar participants. Meanwhile, the characteristics of the participants were based on the status of the residents, $80 \%$ of the participants as students were 10 people, $15 \%$ of the participants as housewives were 2 people, and $8 \%$ of the general participants were only 1 person.

The results of the education questionnaire from the calculations in Table 2 show that the mean or average value of the pretest before giving health education was 63.8462 from 13 participants. Then, after being given health education material about the prevention and spread of COVID-19, it was compared with the value ofpretest, score posttest experienced a change in a higher level of knowledge with an average value of 91.5385 from 13 participants. This can be seen in Figure 2, the understanding of the prevention and recovery of COVID-19 survivors in the community has increased by providing educational materials there is a good comparison of the values before and after (Document attached).

Based on the results of the calculation of the hypothesis test with the method wilcoxon signed ranks test in Table 3 the values that can be known are the mean rank and sum of rank of the negative ranks, positive ranks, and ties groups. Negative ranks is a sample with a value of the second group (post- test) is lower than the value of the first group (pre-test). Whereaspositive ranks is a sample with a value of the second group (post-test) is higher than the value of the first group (pre-test). Ties is the value of the second group (post-test) is equal to the value of the first group (pre-test). The symbol $N$ represents the number of participants, the Mean Rank is the average rank, and the sum of ranks is the sum of the ranks. Then proceed with the calculation of statistical tests using the Wilcoxon Signed Rank Test method in Table 4. The results of these calculations, the $Z$ value obtained is -3.088 withp value (asymp. Sig 2 tailed) of 0.002 , which is smaller than the critical research limit of 0.05 , indicating that there is a significant difference between pre-test and post-test (Attached document).

\section{DISCUSSION}

The implementation of community service activities during the COVID-19 pandemic does not allow crowds and requires service activities to be carried out online via Zoom. The provision of this education is one of the efforts to overcome COVID-19 to break the chain of the spread of COVID-19 in Indonesia. The current condition requires serious efforts in handling the pandemic outbreak in Indonesia. The effort in question is a knowledge strengthening strategy through health education. This is in accordance with a study conducted by (Suadnyani Pasek, 2013) that knowledge itself is the result of human sensing that a person wants to know about objects through the five senses possessed by humans such as sight, hearing, smell, taste, and touch. A person's knowledge is mostly obtained through the sense of hearing and the sense of sight. Also in line with research by Wilandika (2021), has an effort or strategy to strengthen knowledge through health education which is carried out 
directly or online. The success of online health education can be seen from the changes in the level of knowledge and stigma of students which have increased significantly.

According to Rahmawati, (2019), a person's knowledge can be influenced by several factors, namely education, work, information, interests, experience and environment. If someone has more sources of information, then his knowledge is broader and he gains new knowledge. The increase in the number of knowledge from the community is also strongly influenced by interest. This interest is a high desire for something that makes a person try and pursue it, so that someone gains deeper knowledge (Rahmawati et al., 2019). This can be seen when the education carried out by the survivors has high enthusiasm by paying attention to the information and knowledge that has been provided.

The education carried out in this service is in accordance with the recommended actions as an effort to prevent the transmission of COVID-19. Increasing understanding and knowledge about the spread of COVID-19 requires special handling to help minimize these impacts, especially for housewives, students, and the general public. With this extension and health, it is hoped that the survivors will understand the meaning of COVID-19, understand the causes of COVID-19, treatment of COVID-19, prevention of COVID-19, and understand how to deal with anxiety in the midst of this pandemic outbreak. This education is the same as the form of service carried out by Ausrianti (2020) regarding education on preventing the transmission of COVID-19 as well as mental health and psychosocial support for online motorcycle taxi drivers. Community service is carried out online to increase the knowledge of online motorcycle taxi drivers after being given health education materials about COVID-19 in the hope that the drivers understand the meaning of COVID-19, the causes of COVID-19, prevention and understand how to deal with anxiety amid the COVID19 outbreak.

The actions implemented to prevent the transmission or transmission of COVID-19 are implementing health protocols to the public which include the use of protective equipment such as masks, washing hands with soap and running water, maintaining a minimum distance of 1 meter, and increasing body resistance by implementing life-style behaviors. clean and healthy (Brahmana, 2020). According to Purwaningsih, (2021) the central role of women in the current situation is very important to build what values are allowed and not allowed during the pandemic, and understanding the most important knowledge in the formation of a good behavior to think productive efforts and improve activity managers.

\section{CONCLUSIONS AND RECOMMENDATIONS}

The current condition requires serious efforts in handling the pandemic outbreak in Indonesia. So it can be concluded that this education can confirm audiovisually which can change the level of knowledge for the better. This interest is a high desire for something thatmakes a person to try and pursue it, so that someone gains deeper knowledge.

This can be seen during education, the community has high enthusiasm by paying attention to the information and knowledge that has been provided. The education carried out in this service is in accordance with the recommended actions as an effort to prevent the transmission of COVID-19. The actions implemented to prevent the transmission or transmission of COVID-19 are implementing health protocols to the public which include the use of protective equipment such as masks, washing hands with soap and running water, maintaining a minimum distance of 1 meter, and increasing body resistance by implementing life-style behaviors. clean and healthy.

\section{ACKNOWLEDGMENTS}

Thank you to the Institute for Research \& Community Service Sunan Ampel State Islamic University Surabaya. 


\section{REFERENCES}

Adi Saputra, K., Sungkawa, E., \& Ahmad, A. A. (2021). Pengelolaan Standar Kesehatan Pada Rumah Ibadah Dalam Mencegah Penularan Covid-19 Di Kabupaten Tasikmalaya. ABDIMAS: Jurnal Pengabdian Masyarakat, 4(1), 440-445. https://doi.org/10.35568/abdimas.v4i1.1047

Ausrianti, R., Andayani, R. P., Surya, D. O., \& Suryani, U. (2020). Edukasi Pencegahan Penularan Covid 19 serta Dukungan Kesehatan Jiwa dan Psikososial pada Pengemudi Ojek Online. Jurnal Peduli Masyarakat, 2(2), 59-64. https://doi.org/10.37287/jpm.v2i2.101

Brahmana, I. B. (2020). Edukasi Pencegahan Penularan Covid-19 Bagi Tenaga Kesehatan Dan Pasien Di Poliklinik Rawat Jalan Obsgin. Jurnal EMPATI (Edukasi Masyarakat, Pengabdian Dan Bakti), 1(1), 21. https://doi.org/10.26753/empati.v1i1.481

Dewantari, N. M., Ula, S., Muharni, Y., \& Susilo, S. (2021). Pencegahan Stigma Terhadap Orang dalam Penyebutan Covid-19. ABDIMAS: Jurnal Pengabdian Masyarakat, 4(1), 433-439. https://doi.org/10.35568/abdimas.v4i1.1033

Fundrika, B. A. (2021). Bahan Vaksin Covid-19 Oxford Diisukan Terbuat dari Janin, Fakta atau Hoax? https://www.suara.com/health/2020/11/25/185000/bahan-vaksin-covid-19-oxforddiisukan-terbuat-dari-janin-fakta-atau-hoax?page=all

Otálora, M. M. C. (2020). Yuliana. Parque de Los Afectos. Jóvenes Que Cuentan, 2(February), 124-137. https://doi.org/10.2307/j.ctvzxxb18.12

Parwanto, E. (2021). Virus Corona (SARS-CoV-2) penyebab COVID-19 kini telah bermutasi. Jurnal Biomedika Dan Kesehatan, 4(2), 47-49. https://doi.org/10.18051/jbiomedkes.2021.v4.47-49

Purwaningsih, N. S., Fadhilah, H., Ismaya, N. A., \& Sucipto, M. (2021). Education of the Prevention of Covid 19 Transmission and Mental Psychosial Health Support in Households in South Tangerang Banten. Jurnal Abdi Masyarakat, 2(1), 50-59.

Rahayu, R. N. (2021). Vaksin covid 19 di indonesia : analisis berita hoax. 2(07), 39-49.

Rahmawati, A., Nurmawati, T., \& Permata Sari, L. (2019). Faktor yang Berhubungan dengan Pengetahuan Orang Tua tentang Stunting pada Balita. Jurnal Ners Dan Kebidanan (Journal of Ners and Midwifery), 6(3), 389-395. https://doi.org/10.26699/jnk.v6i3.art.p389-395

Ramadhan, M. (2021). Resmi Berlaku, Ini Alasan Pemerintah Terapkan PPKM Darurat Jawa-Bali. https://www.kompas.com/tren/read/2021/07/03/083000865/resmi-berlaku-ini-alasan pemerintah-terapkan-ppkm-darurat-jawa-bali

Suadnyani Pasek, M. (2013). Hubungan Persepsi Dan Tingkat Pengetahuan Penderita Tb Dengan Kepatuhan Pengobatan Di Kecamatan Buleleng. JPI (Jurnal Pendidikan Indonesia), 2(2), 145-152. https://doi.org/10.23887/jpi-undiksha.v2i1.1411

Tim Tribunnews. (2021). Apa Itu Varian Delta? Apa Gejalanya Sama dengan Virus Corona Pada Umumnya? Berikut Penjelasannya. https://www.tribunnews.com/nasional/2021/06/22/apaitu-varian-delta-apa-gejalanya-sama-dengan-virus-corona-pada-umumnya-berikut-penjelasannya

Wilandika, A. (2021). Implementasi Edukasi Kesehatan HIV dalam Perubahan Stigma HIV AIDS pada Mahasiswa Keperawatan. ABDIMAS: Jurnal Pengabdian Masyarakat, 4(1), 405-411. https://doi.org/10.35568/abdimas.v4i1.918 


\section{APPENDIX}

The following is an image that we documented during the implementation of Community Service online via Zoom. The health education counseling provided is knowledge about prevention and transmission of Covid-19 on the perception of survivors.

Table 1. Characteristics of Respondents for the Webinar Education Session

\begin{tabular}{|c|c|c|c|}
\hline \multicolumn{2}{|c|}{ Webinar Education Session Participant Data } & \multirow{2}{*}{$\begin{array}{r}\text { Frequency } \\
2\end{array}$} & \multirow{2}{*}{$\begin{array}{r}\text { Percent } \\
15.4\end{array}$} \\
\hline Gender & Man & & \\
\hline & Woman & 11 & 84.6 \\
\hline & Total & 13 & 100 \\
\hline \multirow[t]{4}{*}{ Citizen Age } & $15-20$ Years & 3 & 23.1 \\
\hline & 21-30 Years & 9 & 69.2 \\
\hline & $>30$ Years & 1 & 7.7 \\
\hline & Total & 13 & 100 \\
\hline \multirow[t]{4}{*}{ Citizen Status } & Student & 10 & 76.9 \\
\hline & Housewife & 2 & 15.4 \\
\hline & General & 1 & 7.7 \\
\hline & Total & 13 & 100 \\
\hline
\end{tabular}

Table 2. Descriptive Statistics

\begin{tabular}{|c|c|c|c|c|c|}
\hline & \multicolumn{2}{|c|}{ Nmean } & Std. Deviation & Minimum & Maximum \\
\hline Pre-test & 13 & 63.8462 & 25.34379 & 10.00 & 90.00 \\
\hline Post-test & 13 & 91.5385 & 10.68188 & 70.00 & 100.00 \\
\hline
\end{tabular}

Table 3. Hypothesis Testing (Wilcoxon Signed Ranks Test)

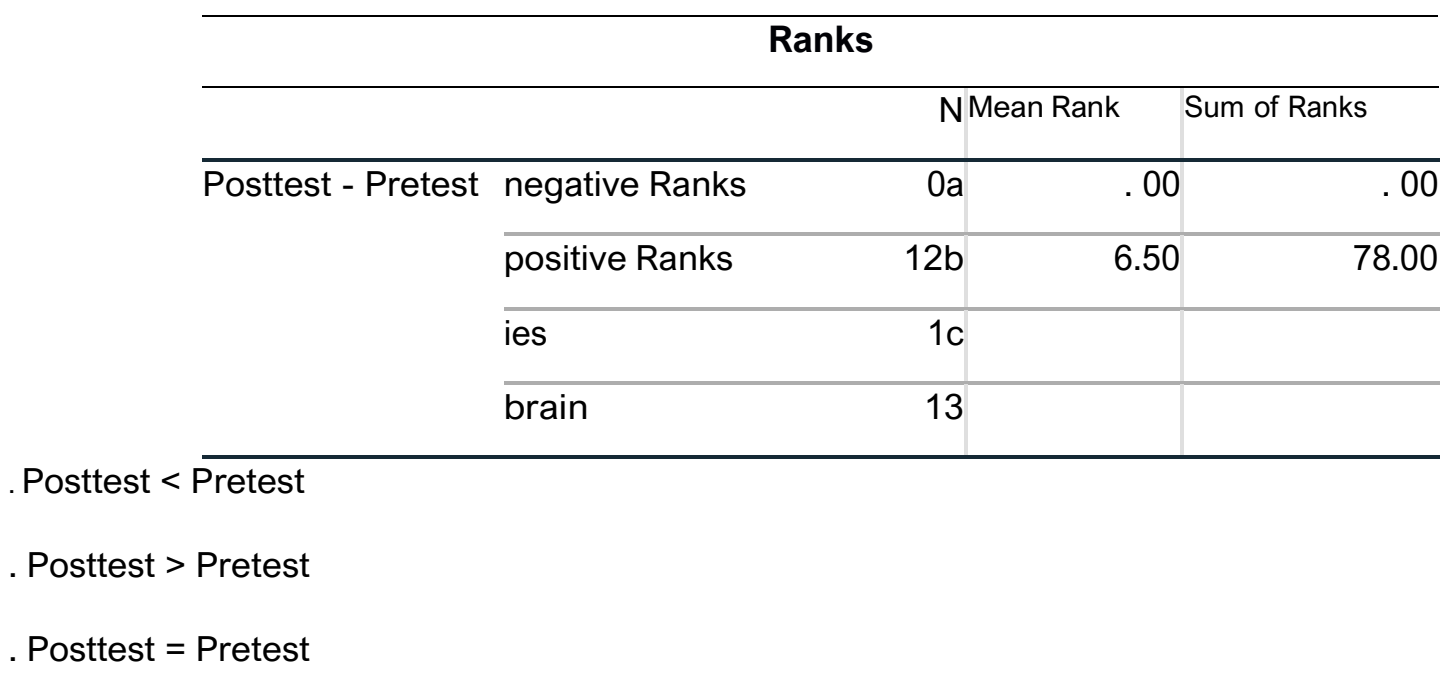


Table 4. Test Statistics

Posttest - Pretest

$-3.088 b$

symp. Sig. (2-tailed)

.002

Wilcoxon Signed Ranks Test

Based on negative ranks.

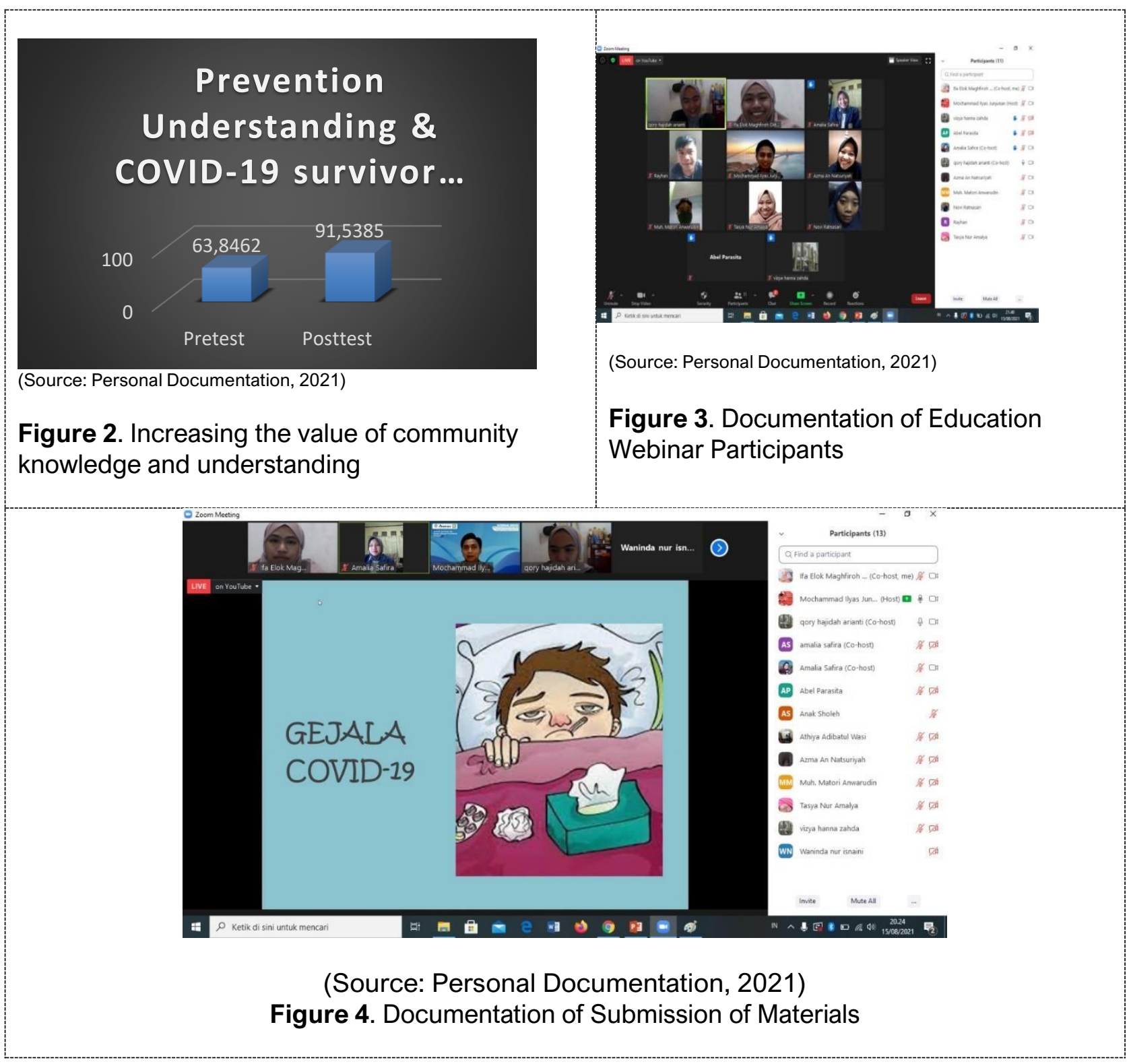

